\title{
The Effect of Learning and Development on Employees' Career Development in NNPC
}

\author{
Egbuta, Olive U. (PhD) \\ Department of Business Administration and Marketing, Babcock University, Ilisan Nigeria
}

\begin{abstract}
The study examine investigate the effect of learning and development practices on employee career development in NNPC. The study adopted descriptive survey research design. The population of the research consisted of 9,024 top level, middle level and lower level management (Supervisors) staff of the NNPC who has spent more than 5 years in the organization and have up to 5 years before retirement age of 60 years and sample size of 1,960 was derived using Slovin formula and purposive sampling procedure. Structured questionnaire with a six point modified Likert- Scale was administered with a $74.6 \%$ response rate (926) copies of the questionnaires came correctly and were used for the study. The obtained from the questionnaire was analyzed quantitatively using descriptive and inferential statistics. The results revealed that learning and development have a significant effect in employee career development in NNPC. The also revealed that that learning and development policy satisfies the career development needs of the employees of the Corporation. But, there is no established career path for every employee and professional groups in NNPC. The study concludes that learning and development practices have significant effect on Employee Career Development in NNPC. The study recommended that NNPC should improve and expand their training programmes for employees by encouraging more employees' participation and free flow of information to enable all the staff aware of the Learning and development programme available both locally and internationally.
\end{abstract}

Keywords: Learning and development practice, Employees career development, NNPC, Corporations, Nigeria DOI: $10.7176 / \mathrm{JRDM} / 56-05$

Publication date: June $30^{\text {th }} 2019$

\section{Introduction}

A vast body of human resources management literature has focused on offering explanation on career development programs aimed at improving performance and productivity in organizations (Patton \& McMahon, 2006; Wane, 2016). Career development theories provide a fundamental explanation describing human behaviour in a particular manner. Career development is a progression of exercises or the continuous procedure of building up one's vocation (Fieldman \&Thomas, 2004). The procedure involves preparing new aptitudes, moving to higher occupation obligations; roll out a profession improvement with a similar association, or beginning one's business. Career development is an effective way organizations use to foster and nurture future leaders within organization with relevant skills and experiences that will be required to implement organization strategies and effectively achieve organization's objectives while assisting the employees to achieve their individual and personal developments.

Career development programs are functions of human resource management that develop the work life and identify competencies required by individual staff to manage their career objective which should be in line with organization objective. They include organizational career planning, employee coaching and mentoring, career counselling, talent management and training and development programs (Prince, 2005). It is the combination and sequence of roles played by a person during the course of a work lifetime (Donald, 2004).

Organizations are facing increased competition due to globalization, changes in technology, political and economic environments (Evans, Pucik \& Barsoux 2002) and therefore prompting these organizations to provide training for their employees as one of the ways to prepare them to adjust to the fast paced changes in the environment and through these enhance their performance. It is important to note that a lot of improvements and changes has taken place in the business and corporate world in the last decade. This growth has been brought about as a result of several factors which includes but not limited to improvements in technology deployed in factors of production, and communication, increase in the complexity in the demand of customers and customer service but also increased efforts towards development of organizational human resources. It is therefore, the responsibility of every organizations to enhance the job performance of the employees. It is in this situation, that the implementation of learning and development programs becomes one of the major steps that most companies need to achieve this. As is evident that employees are a crucial resource, it is important to optimize the contribution of employees to the company aims and goals as a means of sustaining effective performance. This therefore calls for managers to ensure an adequate supply of staff that is technically and socially competent and capable of career development into specialist departments or management positions (Afsham, Sobia, Ahmed, \& Nasir (2012).

In order to succeed, organizations have to obtain and utilize human resources effectively. Organizations, 
therefore, need to design its human resource management in ways that fit into the organization's structure as this it will make the organizations achieve their goals and objectives (Alfa, 2015). Moreover, it is also important for organizations to assist their workforce in obtaining the necessary skills needed and, increase commitment. One way of achieving this is through learning and development. Learning and development are the processes of investing in people so that they are equipped to perform well (Shouvik \& Mohammed, 2018). These processes are part of an overall human resource management approach that hopefully will result in people being motivated to perform. Learning and development helps employees to meet their existing job requirements or helps employees to increase their productivity. An improvement in employee productivity also leads to an improvement in the organization's performance (Khadijetou, 2016).

In the Nigerian National Petroleum Corporation (NNPC), human resources, skills and expertise are crucial assets that drive productivity and performance. This is because, as a regulator of the Nigerian Oil industry, the service provided by NNPC is delivered through its personnel. The employees (human resource) of the NNPC hold the key to the corporation's ability to achieve the objectives for which it was established and the way the organization manages this important resource would determine the extent of its performance (Ameh, 2015). Many researchers believe that, for organizations to maintain an optimum performance they must focus on enhancing performance through a process of continual learning (Hogarh, 2012). The study therefore seeks to investigate the effect of Learning and Development on employee career development at NNPC.

\subsection{Statement of the Problem}

In every organization, the human resources is the most important factor for effective operations, production and service delivery. Recruiting, retaining, training and developing the right and talented people give an organization a competitive edge over its competitors. Learning and development has become a necessity to every organizations; learning and development helps to ensure that organizational members possess the knowledge and skills they need to perform their jobs effectively, take on new responsibilities, and adapt to changing conditions. Despite the recognition of the importance of training by management experts and government as expressed in white papers on various reforms in Nigeria, the experience of manpower training and development in the Nigeria public service has been more of ruse and waste (Okotoni \& Erero, 2005). In the Nigerian Public Service and Federal Parastatals and establishments, which include the NNPC, the procedure for identifying learning and developmental needs, how to address those needs and how to monitor the impact of the training program on the business has always been a challenge (Igbaekemen, 2014).

There are also incidences of politics of training and development where only those in the good books of the Managers and Supervisors are sent on trainings especially overseas courses where the sole purpose may not be necessarily to learn, improve, innovate or develop (Okotoni \& Erero, 2005). There are also the challenges of limited release of training funds by management due to the low importance placed on training, and other learning and development activities and sometimes re-allocation of funds to what management perceives as more important projects and neglecting the fundamental need of reshaping and conditioning the mind-set of employee career development (Obisi, 2011)

In the light of the above and in line with the thinking of Thurber, Emelife and Heller (2010), that NNPC sits at the nexus between the many interests in Nigeria that seek a stake in the country's oil riches, the government, and the private companies that operate most oil and gas projects in the country. Thurber et al (2010) are of the opinion that the best NNPC employees seem to have good expertise in hydrocarbons and genuinely seek the best for the company and the nation, but they often lack the institutional support they need to do their work due to mainly constant political interferences and changes in the corporate governance. There is also the allegation that the worst of the employees use their positions principally as a route to personal gain and development (Thurber et al., 2010).

\section{LITERATURE REVIEW}

\subsection{Theoretical Review}

This study was anchored on the following theories; Reinforcement theory, Social learning theory and Human Capital theory

\subsubsection{Social Learning theory}

The social learning theory was developed by Albert Bandura (1977). The theory emphasizes that people learn by means of observing, imitation and modeling different people (models) whom they believe they are credible and knowledgeable. According to social theory, gaining knowledge of new abilities or behaviours is well done by way of looking at others and seeing the consequences in their behaviour in addition to learning is inspired through someone's self-efficacy, someone's judgment about whether he or she can effectively learn expertise and skills. Further, observation let people to see the consequences of other's behaviours, resulting that people can gain some idea of what might flow from acting in one way or the other. In an organization the environment and the surroundings plays a very important role. The environment should be very professional and the 
surroundings should be in such a way that the people (employees) learn from them. The theory further states that social and interpersonal skills can be learnt by imitation.

Furthermore the theory also explains about the mental states which play a vital role in learning process. If the mental status of the person is negative regarding any learning activity then he will not take part in that learning process and even if he is forced to do so, he will not gain any positivity from that process. In organizational training programs the mental state can be made positive regarding the training and development programs by associating the rewards and benefits with such programs which will motivate the employees and help to build a positive mental state. The case company also follow this theory as it allows the employees to learn from the surrounding and provides an environment where they can learn from their supervisors/managers and coworkers.

Social Learning theory is criticized in that there is a danger in imitation that results in people learning inefficient ways of working or fails to take on board some of the tacit skills used by experienced managers. Social learning theory has sometimes been seen as a bridge between behaviorists and cognitive learning theories because it encompasses attention, memory, and motivation. Lave \&Wenger (1991) and Lava (1992) added that the social approach to learning is through participation in everyday activities. They argued that managers learn through participation in everyday activities and that learning occurs through practice in work situations informally and incidentally. The proponents of this theory holds that most times learning is unintentional and are situated within authentic activity, context and culture of the individual and group participants.

Fox (1997) supports the social learning theory by stating that the key elements of situated learning include people who perform work and belong to a community of practice since it is within a community that learning occurs. Communities of practice have apprenticeship systems (formal and informal) where novices learn by assisting more experienced members. Managers learn through their work and participation in practice. Learning is contextual and in relationship with other people.

\subsubsection{Social Cognitive Career Theory}

Social Cognitive Career Theory (SCCT) (Lent, 2005; Lent, Brown, \& Hackett, 2002) is anchored in Bandura's Social Cognitive theory $(1997,1986,1977)$, and explores how career and academic interests mature, how career choices are developed, and how these choices are turned into accomplishment. This is achieved through a focus of three principles: self-efficacy, outcome expectations, and goals (Lent et al., 1994). Lent (2006) expanded the scope of social cognitive career theory offering a new social cognitive career model. This theory is designed to explain the ways in which previously identified inputs such as self- efficacy and outcome expectations, along with persons are related to job satisfaction. Self-efficacy is concerned with the belief in the ability to exercise control over ones actions and event that affect their lives. Beliefs impact life choices, motivation, quality of actions and the ability to overcome adversity.

Lent (2006) expanded upon Bandura's work to focus exclusively on the development of the individual within the context of career development. Managers who wish to retain talent can borrow from this theory. Career development is driven by self-efficacy or believes in the ability to accomplish something of importance. The degree of achievement depends on two factors, outcome expectations or the idea that initiating a particular behaviour will yield the desired result and goals. Lent (2006) states that if a person feels confident of his or abilities, he or she is more likely to connect to specify actions to reach them. When organizations put in place measures to enhance motivation, they can easily retain talents. The theory associate individual failure to insufficient skill and knowledge which are deemed as acquirable.

This theory associated individual failure to insufficient skill and knowledge which are deemed as acquirable. It is therefore imperative to provide customized training and development opportunities to the employees. This theory is relevant to the current study in that career behavior is driven by self-efficacy or belief in the ability to accomplish something worthwhile. The degree of achievement depends on two factors; outcome expectations or the idea that initiating a particular behavior will yield to desired results. Goals are keys because if a person feels confident of his/her abilities, he's more likely to take specific actions to reach them. If employees feel supported and their goals and career advancement looked into, their intention to stay will be higher.

\subsection{Empirical Literature Review}

\subsubsection{Learning and Development}

Learning and development refers to the process to obtain or transfer knowledge, skills and abilities (KSA) needed to carry out a specific activity or task, therefore, the benefits of learning and development both for employers and employees are strategic in nature and hence much broader. In order to meet the current and future challenges of the business, learning and development assumes a wide range of learning actions, ranging from learning of the employees for their present tasks and more so, knowledge sharing to improve the business horizon and customer's service.

Learning and development has been defined by the Chartered Institute of Personnel Development (CIPD, 2001 ) as: the organizational process of developing people involves the integration of learning and development 
processes, operations and relationships. Its most powerful outcomes for the business are to do with enhanced organizational effectiveness and sustainability. For the individual they are to do with enhanced personal competence, adaptability and employability. It is therefore a critical business process for both profit focused and not-for profit focused organizations.

According to Niazi, (2011) and Mavin (2010), the most essential reason for providing learning and development is to ensure that an organization's employees are able to carry out their current role and to prepare them to maximize their potential and provide valuable resource for the organization, in this light, learning and development thus becomes a source of competitive advantage (Towler \& Dipboye 2009). Schmidt (2007) holds that opportunity for training and development are paramount in decisions regarding employee career choices and HRM Practices must focus on levers of training, career development, and organizational development with the goal of improving processes and enhancing the learning and performance of individuals, organizations, communities, and societies.

Raza (2014) found that training and development of the employees has direct contribution in the high achievement of organizations; this is because, the organization and its growth depend upon the skills and knowledge of the employees which are considered as the valued asset of the firm. The training and development of the employees has direct contributions in the high achievements of organization which shows better performance. Training increased the organizational performance (Hassan et al, 2013). Mohamud (2014) also found that training affects the performance of employee in public sector organization of Kenya. Data was collected from 100 staffs of Machakos branch. Data analysis was done through descriptive statistic. Findings showed that training had an impact on organizational productivity despite the challenges from the management which included: poor motivation, lack of training, lack of compensation policy, poor working conditions, inadequate financial resources to support training, resistance of the top level management to empower junior employees and lack of team spirit among workers. (Mohammed, 2014). The study established that training improved performance and benefits both the individual employees and the organization at large. Also, Adongo (2013) suggested that mostly organization neglects the importance of training which leads to high turnovers and also increased the cost to hire new employees and finally slowed down the organizational profitability. In his study, 419 employees were chosen for data collection in Telkom orange Kenya. Correlation methodology was used in the study. Findings showed that employees feel demotivated by the training offered and indeed many have participated in training programs. In Nigeria, Obi-Anike and Ekwe (2014) bemoaned deficiencies in knowledge, skills, and ability among public personnel. They further established that the public service is sick and barely performs its ordinary function of service delivery. From the review, the results are inconsistent to the extent that learning and development programs all the time are found to contribute to career development and employee performance. Hence, it is hypothesized that:

\subsubsection{Career Development}

$\mathbf{H}_{0}$ : Learning and Development does not play a significant role in Employees' Career Development.

Organizational career development has been defined as sequences of formal and less formal activities of an organization related to the development of the career of its employees, in this context, we see that, organizational career management is expected to increase both employee effectiveness and organizational effectiveness (Kaya $\&$ Ceylan, 2014). Activities around career development involves various alternatives such as developing abilities, preserving current skills and getting prepared for the future ahead after receiving promotion.

Organizations have many motives for investing in career development programs. They include but are not limited to: developing employee performance, increasing manager improvement, revealing and enhancing corporate culture for salespeople, strengthening principal values, helping salespeople in career improvement, and offering an extra to employees $(\mathrm{Ko}, 2012)$. Career development programs enable all the workers to make progress in the organization from the beginning. It also helps individual employee to determine his/her career paths and eliminate all the impediments against the advancement of the employees. Extant researchers (Foongming, 2008; Nwuche \&Awa, 2011; Purcell, Hutchinson, Kinnie, Rayton \& Swart, 2003) identified formal career opportunities is one of key practices which influence organizational performance. Career can be regarded as the successive progress of an employee in his or her chosen field of work throughout life (Nwuche \&Awa, 2011). Foong-ming (2008) sees Career as a "development process of an individual along a path of different work experiences and jobs in one or more organizations" (p. 2). Purcell, Hutchinson, Kinnie, Rayton and Swart (2003) found that providing formal career opportunities is one of key practices which influence organizational performance. Career development increases employee motivation and productivity; and when organizations give attention to Career development it helps them to attract top staff and retain valued employees. Kaya and Ceylan (2014) observe that the goal of the career development system is to fulfil the expectations, desires and objectives of the employees; at the same time, to develop various strategies in accordance with the goals and objectives of the organization. 


\section{Methodology}

This study adopted the descriptive survey research design of the correlational type using questionnaire and structured interview. This design provides the opportunity to establish the relationship between learning and development and employees' career development in NNPC. The adopted research design allowed the researcher to test the hypothesis. The correlational research design is considered because of the relationship between the study variables. A survey is a planned collection of data over a large area for the purpose of analyzing the relationship between variables (Oppenheim, 1992). The study population comprised 9,024 top level, middle level and lower level management (Supervisors) staff of the NNPC who has spent more than 5years in the organization and have up to 5 years before retirement age of 60 years. The NNPC is made up of Twelve Subsidiary companies and two partly owned subsidiaries and some associated companies manage the Upstream, Mid-stream and Downstream activities of the NNPC (NNPC, 2014). Due to this wide geographical spread, limited time factor as well as the financial constraints on the study, the researcher purposefully chose Strategic Business Units (SBUs) in two cities to focus the study on. The cities are Abuja (Corporate Headquarters \& PPMC Headquarters), and Lagos (NAPIMS). The operations of the SBUs chosen cut across the main sectors of the Oil and Gas Business: Upstream, Downstream and Commercial and Investment Sectors. The sampling method employed in this study includes purposive sampling and proportional sampling techniques used in selecting the 944 participants in the SBUs and locations. These were adopted in order to ensure that the different stratum of the management in each location is represented.

This study mainly relied Primary data using a questionnaire. A semi-structured questionnaire were administered to thirteen NNPC Executives and Directors. Questionnaire is appropriate for studies since they collect information that is not directly observable (Franker, 2006; Mellenberg, 2008). Close-ended questions constructed a 6-point Likert scale (1-strongly disagree and 6-strongly agree) provided structured responses that facilitated quantitative analysis, testing of hypothesis, and drawing conclusion. However, open-ended questions provided additional information that may not have been captured by the close-ended questions. In order to explore the factors that can affect employee career development, a pilot study was undertaken. The pilot study was carried out at the NNPC/PPMC Mosimi Area Office in Ogun State which is another section of the organization that is not part of the study population. A total of 100 questionnaires were distributed and 94 were returned.

Face and content validity of the questionnaire items for the two research variables were verified. The drafted copies of the questionnaire were given to Specialists in Human Resources and Strategic Management to look at the structure and construction of questions in order to ensure accuracy and that it aligns with the different dimensions of the study. Furthermore, factor analysis confirmed that the study variables had construct validity as recommended by Kerlinger and Lee (2000). The reliability of the instrument was established through Cronbach's Alpha coefficient for each variable. Cronbach's alpha values for the study variables were established at 0.74 and 0.73 for learning and development and employee career development respectively which lie within the threshold of at least 0.7 recommended by Nunnally and Bernstein (1994). On the basis of reliability test it was supposed that the scales used in this study is reliable to capture the variables. The researcher administered the questionnaire through hand-delivery and collected the completed copies of questionnaire later.

The data collected were analyzed using descriptive statistical tools which helped the researcher to describe the data and determine the extent used. This included frequency distributions, tables, percentages, mean, and standard deviation. Data analysis was done with the use of SPSS and Microsoft excel. Tables were used to summarize responses for further analysis and facilitate comparison. Simple regression model was used to test the hypothesis formulated. The hypothesis formulated was tested for significance at 0.05 level of significance.

\section{Results and Discussion}

The researcher administered 1235 copies of the questionnaire, out of which 926 were filled-in and returned translating to $74.9 \%$ response rate. The remaining 309 copies of the questionnaire could not be retrieved because the participants did not continue with the study while others were not properly filled or mutilated. This response rate is considered sufficient for making inferences and drawing conclusions from the research data.

\subsection{Descriptive Statistics}

The study sought to determine the extent to which respondents agreed with the following statements assessing the learning and development practices in NNPC and employee career development. The sample measures that were pertinent to the objectives of this study were frequency, percentages, mean and standard deviation were used as a basis summarizing, describing and comparing research variables numerically as well as revealing pattern of sample data set. 
Table 1: Descriptive Results for Learning and Development Learning and Development Practices

Overall, how satisfied are you with the training, Learning and Development you've received since you were employed into the NNPC?

What is the level of your satisfaction with the NNPC Learning and Development Policy

How satisfied are you with the Training Plan the NNPC has made for you

What is the level of your satisfaction regarding the process of Training Needs identification processes of the Corporation

How satisfied are you with the detailed Training Plans of the Corporation

How satisfied are you with the way

Training received is monitored and evaluated on performance

How satisfied with the value the NNPC gets with the huge amount spent on Learning \& Development

How satisfied are you with the opportunity you have to apply the news skills you have learnt from training to your job?

How satisfied are you with the opportunities available for you in your Department to work with a mentor?

How satisfied are you with the opportunities your job provides you to cross-train and learn new skills?

How satisfied are you with the opportunity for career development within the company?

How satisfied are you with the following:

How satisfied are you with the organization's training / orientation for new employees?

How satisfied are you with the training you received to do your job you were employed to do?

How satisfied are you with the available training provided to advance in your department and discipline?

How satisfied are you with the available training you can take to transfer into another part of the company?

\begin{tabular}{|c|c|c|c|c|c|c|c|}
\hline $\begin{array}{l}\text { VS } \\
(\%)\end{array}$ & $\begin{array}{c}S \\
(\%)\end{array}$ & $\begin{array}{c}\text { SS } \\
(\%)\end{array}$ & $\begin{array}{l}\text { SD } \\
(\%)\end{array}$ & $\begin{array}{c}\text { D } \\
(\%)\end{array}$ & $\begin{array}{l}\text { VD } \\
(\%)\end{array}$ & $X$ & SD \\
\hline $\begin{array}{c}77 \\
(8.3)\end{array}$ & $\begin{array}{c}136 \\
(14.7)\end{array}$ & $\begin{array}{c}22 \\
(2.4)\end{array}$ & $\begin{array}{c}182 \\
(19.7)\end{array}$ & $\begin{array}{c}196 \\
(21.2)\end{array}$ & $\begin{array}{c}303 \\
(32.7)\end{array}$ & 3.80 & 1.252 \\
\hline $\begin{array}{c}35 \\
(3.8)\end{array}$ & $\begin{array}{c}85 \\
(9.2)\end{array}$ & $\begin{array}{c}573 \\
(61.9)\end{array}$ & $\begin{array}{l}152 \\
(16.4)\end{array}$ & $\begin{array}{c}30 \\
(3.2)\end{array}$ & $\begin{array}{c}39 \\
(4.2)\end{array}$ & 3.61 & 1.234 \\
\hline $\begin{array}{c}41 \\
(4.4)\end{array}$ & $\begin{array}{c}158 \\
(17.1)\end{array}$ & $\begin{array}{c}58 \\
(6.3)\end{array}$ & $\begin{array}{c}216 \\
(23.3)\end{array}$ & $\begin{array}{c}176 \\
(19.0)\end{array}$ & $\begin{array}{c}256 \\
(27.6)\end{array}$ & 3.53 & 1.378 \\
\hline $\begin{array}{c}32 \\
(3.5)\end{array}$ & $\begin{array}{c}164 \\
(17.7)\end{array}$ & $\begin{array}{c}47 \\
(5.1)\end{array}$ & $\begin{array}{c}170 \\
(18.4)\end{array}$ & $\begin{array}{c}225 \\
(24.3)\end{array}$ & $\begin{array}{c}273 \\
(29.5)\end{array}$ & 3.59 & 1.294 \\
\hline $\begin{array}{c}27 \\
(2.9)\end{array}$ & $\begin{array}{c}235 \\
(25.4)\end{array}$ & $\begin{array}{c}52 \\
(5.6)\end{array}$ & $\begin{array}{c}185 \\
(20.0)\end{array}$ & $\begin{array}{c}180 \\
(19.4)\end{array}$ & $\begin{array}{c}232 \\
(25.1)\end{array}$ & 3.52 & 1.327 \\
\hline $\begin{array}{c}43 \\
(4.6)\end{array}$ & $\begin{array}{c}188 \\
(20.3)\end{array}$ & $\begin{array}{c}60 \\
(6.5)\end{array}$ & $\begin{array}{c}182 \\
(19.7)\end{array}$ & $\begin{array}{c}197 \\
(21.3)\end{array}$ & $\begin{array}{c}233 \\
(25.2)\end{array}$ & 3.4208 & 1.38569 \\
\hline $\begin{array}{c}34 \\
(3.7)\end{array}$ & $\begin{array}{c}70 \\
(7.6)\end{array}$ & $\begin{array}{c}196 \\
(21.2)\end{array}$ & $\begin{array}{c}221 \\
(23.9)\end{array}$ & $\begin{array}{c}180 \\
(19.4)\end{array}$ & $\begin{array}{c}207 \\
(22.4)\end{array}$ & 3.4055 & 1.36483 \\
\hline $\begin{array}{c}48 \\
(5.2)\end{array}$ & $\begin{array}{c}48 \\
(5.2)\end{array}$ & $\begin{array}{c}162 \\
(17.5)\end{array}$ & $\begin{array}{c}203 \\
(21.9)\end{array}$ & $\begin{array}{c}226 \\
(24.4)\end{array}$ & $\begin{array}{c}230 \\
(24.8)\end{array}$ & 3.6159 & 1.32078 \\
\hline $\begin{array}{c}41 \\
(4.4)\end{array}$ & $\begin{array}{c}220 \\
(23.8)\end{array}$ & $\begin{array}{c}233 \\
(25.2)\end{array}$ & $\begin{array}{c}195 \\
(21.1)\end{array}$ & $\begin{array}{c}155 \\
(16.7)\end{array}$ & $\begin{array}{c}60 \\
(6.5)\end{array}$ & 3.4372 & 1.36585 \\
\hline $\begin{array}{c}48 \\
(5.2)\end{array}$ & $\begin{array}{c}74 \\
(8.0)\end{array}$ & $\begin{array}{c}173 \\
(18.7)\end{array}$ & $\begin{array}{c}213 \\
(23.0)\end{array}$ & $\begin{array}{c}178 \\
(19.2)\end{array}$ & $\begin{array}{c}222 \\
(24.0)\end{array}$ & 3.5077 & 1.40875 \\
\hline $\begin{array}{c}42 \\
(4.5)\end{array}$ & $\begin{array}{c}197 \\
(21.3)\end{array}$ & $\begin{array}{c}62 \\
(6.7)\end{array}$ & $\begin{array}{c}216 \\
(23.3)\end{array}$ & $\begin{array}{c}173 \\
(18.7)\end{array}$ & $\begin{array}{c}217 \\
(23.4)\end{array}$ & 3.5000 & 1.37036 \\
\hline $\begin{array}{c}49 \\
(5.3)\end{array}$ & $\begin{array}{c}54 \\
(5.8)\end{array}$ & $\begin{array}{c}200 \\
(21.6)\end{array}$ & $\begin{array}{c}180 \\
(19.4)\end{array}$ & $\begin{array}{c}172 \\
(18.6)\end{array}$ & $\begin{array}{c}257 \\
(27.8)\end{array}$ & 3.6133 & 1.38764 \\
\hline $\begin{array}{c}45 \\
(4.9)\end{array}$ & $\begin{array}{c}181 \\
(19.5)\end{array}$ & $\begin{array}{c}49 \\
(5.3)\end{array}$ & $\begin{array}{c}181 \\
(19.5)\end{array}$ & $\begin{array}{c}161 \\
(17.4)\end{array}$ & $\begin{array}{c}297 \\
(32.1)\end{array}$ & 3.5597 & 1.28791 \\
\hline $\begin{array}{c}45 \\
(4.9)\end{array}$ & $\begin{array}{c}49 \\
(5.3)\end{array}$ & $\begin{array}{c}191 \\
(206)\end{array}$ & $\begin{array}{c}206 \\
(22.2)\end{array}$ & $\begin{array}{c}199 \\
(21.5)\end{array}$ & $\begin{array}{c}222 \\
(24.0)\end{array}$ & 3.5033 & 1.35622 \\
\hline $\begin{array}{c}36 \\
(3.9)\end{array}$ & $\begin{array}{c}133 \\
(14.4)\end{array}$ & $\begin{array}{c}70 \\
(7.6)\end{array}$ & $\begin{array}{c}156 \\
(16.8)\end{array}$ & $\begin{array}{c}217 \\
(23.4)\end{array}$ & $\begin{array}{c}295 \\
(31.9)\end{array}$ & 3.3148 & 1.33516 \\
\hline
\end{tabular}

Note: $\bar{X}=$ mean, VS=Very Satisfied, $\mathrm{S}=$ Satisfied, $\mathrm{SS}=$ Slightly Satisfied, $\mathrm{SD}=$ Slightly Dissatisfied, $\mathrm{D}=$ Dissatisfied, VD = Very Dissatisfied

\section{Source: Researcher's Field Survey Result, 2016}

Table 1 presents respondents opinion on learning and development scale. Examining the data in Table 1 shows that $573(61.9 \%)$ of the respondents are not satisfied with the NNPC Learning and Development Policy; $668(72.1 \%)$ are not satisfied with the Training Plan the NNPC has made for them and with the process of Training Needs identification processes of the Corporation,. The staff also expressed dissatisfaction with way the 
Training received by employees are monitored and evaluated on performance; this was reported by $612(66.1 \%)$ of the respondents. Furthermore, the staff are not satisfied with the value the NNPC gets with the huge amount spent on Learning \& Development as a total of 608 (65.6\%) reported that. The employee are also not satisfied with the opportunity given them to apply the new skills they had learnt from training to their job, this was reported by $659(71.2 \%)$, while $648(69.9 \%)$ are not satisfied with the opportunities available for them in their Department to work with a mentor; just as 613 ( $66.2 \%$ ), are not satisfied with the opportunities their job provides them to cross- posting to train and learn new skills, still yet a total of $606(65.4 \%)$ are not satisfied with the opportunity for Career development within the company. On the issue of the level of satisfaction with the organization's training / orientation for new employees 609 (65.8\%), and 639 (69\%) said they are not satisfied with the training they received to do the job they were employed to do; while $627(67.7 \%)$, are not satisfied with the available training provided to advance in their department and discipline and $668(72.1 \%)$ of the respondents are not satisfied with the available training they need to transfer into another part of the company. Overall, $68.1 \%$ of the respondents are not satisfied with the Training, Learning and Development they had received since they were employed into the NNPC.

It is apparent from the results in Table 1 above that learning and development policy satisfies the career development needs of the employees of the Corporation because the training programme and learning and development practices are aligned with the individual career needs. Furthermore, from the data, it can be adduced that the detailed Training Plans of the Corporation is acceptable to the employees because there is an alignment with individual Career development and the Training received are monitored and evaluated on performance and the consequence of this, is that the NNPC is getting much value for the huge amount of resources the corporation invests in Learning and Development. In addition, the result shows that employees were satisfied with the opportunities available for them in their Department to be assigned to work with a mentor and the opportunities their job provides them to cross-train and learn new skills. Table 2 presents the descriptive statistics analysis for career development in NNPC. 
Table 2: Descriptive Statistics for Employees' Career Development

\begin{tabular}{|c|c|c|c|c|c|c|c|c|}
\hline Career and Development & 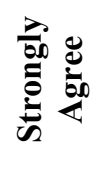 & 总 & 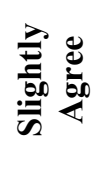 & 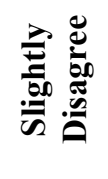 & 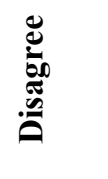 & 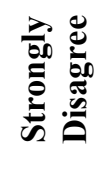 & 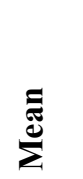 & 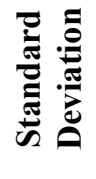 \\
\hline $\begin{array}{l}\text { NNPC has an established career path the } \\
\text { corporation use for every employee \& } \\
\text { professional groups }\end{array}$ & $\begin{array}{c}47 \\
(5.1)\end{array}$ & $\begin{array}{c}83 \\
(9.0)\end{array}$ & $\begin{array}{c}112 \\
(12.1)\end{array}$ & $\begin{array}{c}273 \\
(29.5)\end{array}$ & $\begin{array}{c}194 \\
(21.0)\end{array}$ & $\begin{array}{c}162 \\
(17.5)\end{array}$ & 3.01 & 1.510 \\
\hline $\begin{array}{l}\text { Employees in the corporation understand } \\
\text { what to do to at any time to make progress } \\
\text { in their career. }\end{array}$ & $\begin{array}{c}56 \\
(6.0)\end{array}$ & $\begin{array}{c}155 \\
(16.7)\end{array}$ & $\begin{array}{c}62 \\
(6.7)\end{array}$ & $\begin{array}{c}173 \\
(18.7)\end{array}$ & $\begin{array}{c}195 \\
(21.1)\end{array}$ & $\begin{array}{c}260 \\
(28.1)\end{array}$ & 3.51 & 1.941 \\
\hline $\begin{array}{l}\text { Training and development opportunities are } \\
\text { explicitly linked to the strategic direction of } \\
\text { NNPC }\end{array}$ & $\begin{array}{l}23 \\
(2.5)\end{array}$ & $\begin{array}{l}47 \\
(5.1)\end{array}$ & $\begin{array}{l}200 \\
(21.6)\end{array}$ & $\begin{array}{l}203 \\
(21.9)\end{array}$ & $\begin{array}{l}199 \\
(21.5)\end{array}$ & $\begin{array}{l}238 \\
(25.7)\end{array}$ & 3.50 & 1.637 \\
\hline $\begin{array}{l}\text { Employees in NNPC receive formal Career } \\
\text { advice from their Supervisors and } \\
\text { Managers. }\end{array}$ & $\begin{array}{l}39 \\
(4.2)\end{array}$ & $\begin{array}{l}69 \\
(7.5)\end{array}$ & $\begin{array}{l}149 \\
(16.1)\end{array}$ & $\begin{array}{l}215 \\
(23.2)\end{array}$ & $\begin{array}{l}214 \\
(23.1)\end{array}$ & $\begin{array}{l}224 \\
(24.2)\end{array}$ & 3.52 & 1.352 \\
\hline $\begin{array}{l}\text { There is a Formal Mentoring and Career } \\
\text { Development workshops, }\end{array}$ & $\begin{array}{l}29 \\
(3.1)\end{array}$ & $\begin{array}{l}100 \\
(10.8)\end{array}$ & $\begin{array}{l}180 \\
(19.4)\end{array}$ & $\begin{array}{l}182 \\
(19.7)\end{array}$ & $\begin{array}{l}215 \\
(23.2)\end{array}$ & $\begin{array}{l}202 \\
(21.8)\end{array}$ & 3.26 & 1.425 \\
\hline $\begin{array}{l}\text { Employees in the corporation know what } \\
\text { the key skills are that Corporation needs in } \\
\text { the next five years to achieve its objectives. }\end{array}$ & $\begin{array}{l}18 \\
(1.9)\end{array}$ & $\begin{array}{l}159 \\
(17.2)\end{array}$ & $\begin{array}{l}117 \\
(12.6)\end{array}$ & $\begin{array}{l}167 \\
(18.0)\end{array}$ & $\begin{array}{l}199 \\
(21.5)\end{array}$ & $\begin{array}{l}245 \\
(26.5)\end{array}$ & 3.21 & 1.698 \\
\hline $\begin{array}{l}\text { The business strategy of the Corporation is } \\
\text { consistently communicated to all levels of } \\
\text { employees though the management chain, } \\
\text { through special communications and } \\
\text { through training and development activities }\end{array}$ & $\begin{array}{l}27 \\
(2.9)\end{array}$ & $\begin{array}{l}177 \\
(19.1)\end{array}$ & $\begin{array}{l}88 \\
(9.5)\end{array}$ & $\begin{array}{l}185 \\
(20.0)\end{array}$ & $\begin{array}{l}193 \\
(20.8)\end{array}$ & $\begin{array}{l}234 \\
(25.3)\end{array}$ & 3.33 & 1.690 \\
\hline $\begin{array}{l}\text { Employees are actively encouraged to share } \\
\text { their knowledge with colleagues, not just } \\
\text { subordinates, by coaching, mentoring and } \\
\text { formal training within their work group and } \\
\text { cross-functionally }\end{array}$ & $\begin{array}{l}23 \\
(2.5)\end{array}$ & $\begin{array}{l}96 \\
(10.4)\end{array}$ & $\begin{array}{l}35 \\
(3.8)\end{array}$ & $\begin{array}{l}145 \\
(15.7)\end{array}$ & $\begin{array}{l}497 \\
(53.7)\end{array}$ & $\begin{array}{l}153 \\
(16.5)\end{array}$ & 2.38 & 1.996 \\
\hline $\begin{array}{l}\text { There is ample Career advancement } \\
\text { opportunities that is open to all relevant } \\
\text { employees in the corporation }\end{array}$ & $\begin{array}{l}39 \\
(4.2)\end{array}$ & $\begin{array}{l}191 \\
(20.6)\end{array}$ & $\begin{array}{l}53 \\
(5.7)\end{array}$ & $\begin{array}{l}220 \\
(23.8)\end{array}$ & $\begin{array}{l}186 \\
(20.1)\end{array}$ & $\begin{array}{l}219 \\
(23.7)\end{array}$ & 3.51 & 1.341 \\
\hline $\begin{array}{l}\text { There is visibility to Senior management in } \\
\text { the organization on matters of Career } \\
\text { Development }\end{array}$ & $\begin{array}{l}27 \\
(2.9)\end{array}$ & $\begin{array}{l}167 \\
(18.0)\end{array}$ & $\begin{array}{l}72 \\
(7.8)\end{array}$ & $\begin{array}{l}211 \\
(22.8)\end{array}$ & $\begin{array}{l}216 \\
(23.3)\end{array}$ & $\begin{array}{l}210 \\
(22.7)\end{array}$ & 3.37 & 1.373 \\
\hline
\end{tabular}

\section{Source: Researcher's Field Survey Result, 2016}

Table 2 presents respondents opinion on Career Development measuring scale. The results of descriptive analysis showed that NNPC does not have established Career path for employees and professional groups as reported by $629(67.9 \%)$. The majority $(67.8 \%)$ of respondents indicates that employees in NNPC do not understand what to do at any time to make progress in their career (strongly disagreed, disagreed and slightly disagreed combined). Also, the Table revealed that in the Corporation, majority of the respondents (69.1\%) disagreed that training and development opportunities are explicitly linked to the strategic direction of NNPC.

Furthermore, the result reveals that employees in NNPC do not receive formal Career advice from their supervisors and managers. A total of $70.5 \%$ of the respondents confirm this. 599 or $64.7 \%$ of the respondents declined that there is a Formal Mentoring and Career Development workshops in the Corporation, $(65.9 \%)$ disagreed that employees in the corporation know what the key skills are that Corporation needs in the next five years to achieve its objectives, $(61.2 \%)$ are of the view that the business strategy of the Corporation is not consistently communicated to all levels of employees through the management chain, through special communications and through training and development activities, $(85.9 \%)$ reflect that employees are not actively encouraged to share their knowledge with colleagues, not just subordinates, by coaching, mentoring and formal training within their work group and cross-functionally, $(67.5 \%)$ disagreed that there is ample Career advancement opportunities that is open to all relevant employees in the corporation and (68.8\%) disagreed that there is visibility to Senior management in the organization on matters of career development.

It is evident from the results of descriptive analysis about career development that there is no established 
career path for every employee and professional groups in NNPC; and training and development opportunities are not explicitly linked to the strategic direction of NNPC. As a result, employees do not really know the key skills that Corporation needs to achieve its objectives. In addition, employees in NNPC do not receive formal Career advice from their Supervisors and Managers.

\subsection{Test of Hypothesis}

A univariate analysis was used to empirically test the hypothesis formulated for this study. The hypothesis was tested at $95 \%$ level of confidence as a statistical basis for drawing conclusion. The responses for each variable were combined to generate composite scores which were used in the regression analysis. Learning and development variable was regressed on employee Career Development as shown in Table 3.

Table 3: Regression Model Test of Analysis of Effect of Learning and Development Practices on Employee Career Development

\begin{tabular}{|c|c|c|c|c|c|}
\hline & \multicolumn{2}{|c|}{$\begin{array}{l}\text { Unstandardized } \\
\text { Coefficients }\end{array}$} & \multirow{2}{*}{$\begin{array}{c}\text { Standardized Coefficients } \\
\text { Beta }\end{array}$} & \multirow[b]{2}{*}{$\mathrm{t}$} & \multirow[b]{2}{*}{ Sig. } \\
\hline & $\mathrm{B}$ & Std error & & & \\
\hline Constants & 5.472 & .877 & & 6.237 & .000 \\
\hline Learning and Development Practices & .461 & .014 & .734 & 32.691 & .000 \\
\hline $\begin{array}{l}\mathrm{R}=0.734 \quad \mathrm{R}^{2}=0.539 \\
\text { Durbin Watson }=1.595\end{array}$ & & & $=1068.694_{1 / 925}, p=0.000$ & & \\
\hline
\end{tabular}

a. Dependent variable: Employee Career Development

Source: Researcher's Field Survey from SPSS output, 2016

Table 3 shows result of regression analysis of effect of learning and development practices on employee career development in NNPC. The result reveals that Learning and Development practices has positive and significant effect on employee career development in NNPC $(\beta=.461, t=32.691, p>0.05)$. The finding shows that learning and development practices have statistically significant effect on employee career development in NNPC $(F=1068.694, \mathrm{p}>0.05)$. Furthermore, the Table shows that Learning and Development practices contribute almost $54 \%$ variance in employees' career development. Also, as indicated in the table 3 above, since p-value calculated is less than the critical level of significance $(0.000<0.05$, the null hypothesis (Ho) was rejected implying that learning and development have a significant effect in employee career development in NNPC.

\section{Discussion}

The results from this study show that Learning and Development can significantly affect Employee Career Development. This corroborates the submission of Hassan (2014) who found that majority of the employees were satisfied with the strategic training and development (T\&D) of the firm linking their performance to the quality of training and development they have received. The result agrees with the findings of Hassan, Razi; Jaffir, and Suhail (2013) that there is a positive relationship between job training and employee retention and that both female and male employee has their interest in participating in training. Rewards and supervisory support is found to be the demand of employees irrespective of female or male. Both male and female required Supervisory support irrespective of their gender.

The results is in line with the findings of Abdul, Ahmad and Amram (2012) that training has insignificant relationship with job turnover, whereas job satisfaction and alternative job are positively related to job turnover. Ali and Shahrooz (2012) findings revealed that many factors can affect the effectiveness of training including lack of support from top management and peers, employees' individual attitudes, job-related factors and also the deficiencies in training practice. Raja, Furqan and Muhammad (2011) findings revealed that Training and Development, On-the-Job Training, Training Design and Delivery style have significant effect on employee performance and all these have positive affect on the organizational performance. This means that the overall performance of the organization improved because of the training that the employees received. Additionally, Anam, Rashid and Rab (2013) found that training leads to important benefits for individuals and teams, organizations and society and these benefits extend from individual and team performance to the economic prosperity of a nation.

The findings of this study are however in contrast with some of the opinions of respondents regarding Learning and Development practices in NNPC. $61.9 \%$ of the respondents were not satisfied with the NNPC Learning and Development Policy. Also, $72.1 \%$ of the respondents are not satisfied with the Training Plan the NNPC has made for them. Further, $66.1 \%$ are not satisfied with the process of Training Needs identification processes of the Corporation. Similarly, $65.6 \%$ are not satisfied with the way Training received is monitored and evaluated on performance.

\section{Conclusion and Recommendations}

The study analyzed the effect of learning and development practices on Employee Career Development in NNPC. 
Based on the findings of the study, it was concluded that learning and development have a significant effect in employee career development in NNPC. It was also discovered that learning and development policy satisfies the career development needs of the employees of the Corporation because the training programme and learning and development practices are aligned with the individual career needs. Furthermore, from the data, it can be adduced that the detailed Training Plans of the Corporation is acceptable to the employees because there is an alignment with individual Career development and the Training received are monitored and evaluated on performance and the consequence of this, is that the NNPC is getting much value for the huge amount of resources the corporation invests in Learning and Development. The study thus recommended that there is need for proper training at all levels. The strong linkage between training and job performance has necessitated the need for the NNPC to intensify the efforts and strategy to engaged employees in formal training for growth and development as well as high job performance. Thus, NNPC should improve and expand their training programmes for employees by encouraging more employees' participation and free flow of information to enable all the staff aware of the Learning and development programme available both locally and internationally.

\section{References}

Abdul, H.A.D., Ahmed, J \& Amram. R (2012). The Impact of Training, Job Satisfaction and Alternative Job Opportunities on Job Turnover in Libyan Oil Companies Procedia Social and Behavioral Sciences; Elservier 40 389-394

Adongo, A.J (2014). Examining the effects of Job Training on Employees performance in Mobile Telephone Industry: A Case of Telkom Orange; Nakuru, Kenya (A Doctoral Dissertation).

Ali, M \& Shahrooz, F (2012). Assessment Effectiveness on the Job of Training in Higher Education (Case Study: Takestan University) Procedia Social and Behavioral Sciences. Elservier 47. 1310-1314)

Hogarh, J. K (2012). The effect of training on staff performance: A case study of Sic Insurance Company Limited. A Thesis submitted to the Institute of Distance Learning, Kwame Nkrumah University of Science and Technology in partial fulfillment of the requirements for the degree of Commonwealth Executive Masters in Business Administration. Institute of Distance Learning, Ghana.

Bandura, A. (1977). Social learning theory. Englewood Cliffs, NJ: Prentice-Hall.

Bandura. A. (1999). Social Cognitive theory: An Agentic Perspective. Asian Journal of Social Psychology. 2(1) 21-41

Fox, S (1997). Situated Learning Theory versus traditional cognitive learning theory: why management education should not ignore management learning. Systems practice, 10(6) 727-747

Obi-Anike, H. O., \& Ekwe, M, C. (2014). Impact of training and development on organizational effectiveness: Evidence from selected public sector organizations in Nigeria. European Journal of Business and Management, 6(29), 66-75.

Alfa, M. E. (2015). Evaluation of the effect of manpower training and development in service organization: A study of Power Holding Company, Zaria Zone. A Thesis submitted to the School of Post Graduate Studies Ahmadu Bello University, Zaria In partial fulfillment of the requirements for the award of Masters of Science degree in public administration, department of public administration, faculty of administration, Ahmadu Bello University, Zaria, Nigeria.

Shouvik, S., \& Mohammed, W. H. (2018). Impact of training and development on the performance of employees - A comparative study on select banks in Sultanate of Oman. International Journal of Scientific Research and Management, 6(3), 191-198.

Khadijetou, W. (2016). Effect of Career Development programs on employee retention in international nongovernmental organizations in Kenya. A research project submitted in partial fulfillment of the requirements for the award of the degree of Master of Business Administration (MBA), School of Business, and University of Nairobi, Kenya

Lave, J \& Wenger, E (1990). Situated Learning: Legitimate Peripheral Participation, Cambridge, UK: Cambridge University Press

Lave. J (1996). Learning as Participation in Communities of Practice. Teaching As a learning In Practice. Mind Culture and Activity, 3(3).149-164

Lent, R. W., Brown, S. D. \& Hackett, G. (1994). Toward a Unifying Social Cognitive Theory of Career and Academic interest choice and performance. Journal of Vocational Behaviour 45(1) 79-122

Lent, R. W. (2005). A Social Cognitive View of Career Development and Counselling. In S.D. Brown \& R.T. Lent (Eds.). Career development and Counselling: Putting theory and Research to work (101-127)

Lent, R. W., Brown, S. D. \& Hackett, G. (2002). Social Cognitive Theory; in S. D Brown \& Associates (Eds.). Career Choice and Development. (4th Ed. 255-311). San Francisco, CA. Jossey-Bass

Niazi, A. S. (2011). Training and Development Strategy and Its Role in Organizational Performance. Journal of Public Administration and Governance, 1(2)

Mavin, S (2010). The Evaluation of Learning and Development in the Workplace: A Review of Literature. 
Higher Education Funding Council for England

Patton, W \& McMahon, and M. (2006). The Systems Theory Framework of Career Development and Counseling: Connecting Theory to Practice. International Journal for the Advancement of Counseling 28(2) 153-166 Spinger

Wane, K (2016). Effect of Career Development Programs on Employee Retention in International NonGovernmental Organization in Kenya (A Research Project Submitted to the University of Nairobi as partial requirement for the award of an MBA Degree).

Towler, A. J, \& Dipboye, R. L. (2009). Effects of Trainer Expressiveness, Organizational and Training Orientation on Training Outcomes. Journal of Applied Psychology, 86(4), 230-240

Thurber, M. C., Emelife I. E., \& Heller, P. R.P. (2010). NNPC and Nigeria's Oil Patronage Ecosystem. Program on Energy and Sustainable Development: Institute For International Studies; Working Paper No, 95 : Leadership Quarterly, 15, 175-195.

Raza, H. (2014). Training and Development impact on Organizational Performance: Empirical Evidence from Oil and Gas Sector of Pakistan. Journal of Business and Management, 16(1)

Schmidt, S. W. (2007). The Relationship between Satisfaction with Workplace Training and Overall Job Satisfaction. Human Resource Development Quarterly, 18(4), Winter 2007; Wiley Periodicals, Inc.

Afshan, S., Sobia, I., Kamran, A. \& Nasir, M. (2012). Impact of training on employee performance: A study of Telecommunication Sector in Pakistan. Interdisciplinary Journal of Contemporary Research in Business 4(6)

Hassan, M. (2014). Training and Development Impact on Organizational Performance: Empirical Evidence from Oil and Gas Sector of Pakistan Oil and Gas Sector'. Journal of Business and Management, 16(1), 167-172

Hassan, W., Razi, A., Qamar, R., Jaffir, R. \& Suhail, S. (2013). The Effect of Training on Employee Retention. Global Journal of Management and Business Research Administration and Management, 13(6)

Mohamed, A. M. (2014). The Effects of Training on Employee Performance in Public Sector Organizations in Kenya. The Case of the NHIF Machakos Community. An Unpublished Research Project Submitted to the University Of Niarobi in Partial Fulfilment for the Requirement of Master of Arts Degree in Project Planning and Management, University Of Nairobi

Prince, B.J. (2005). Career-Focused Employee Transfer Processes. Career Development International, 10, 293 309. Accessed November, 2018

Evans, P, Pucik. V \& Barsoux, J.L. (2002). The Global Challenge - Frameworks for International Human Resource Management McGraw Hill/Irwin, 2002.

Fieldman, D.C., \& Thomas, D.C. (2004). Career Management issues facing expatriates. Journal of International Business, 23(2), 271-293.

Ameh, M. O. (2015). Efficient Management of Nigeria Oil and Gas Industry: www.thisdaylive.com/aricle/efficient.

Shouvik, S \&Mohammed W. H. (2018). The Impact of Teamwork on Work Performance of Employees: A Study of Faculty Members in Dhofar University. IOSR Journal of Business and Management (IOSR-JBM) eISSN: 2278-487X, p-ISSN: 2319-7668. Volume 20, Issue 3. Ver. I (March. 2018), PP 15-22 www.iosrjournals.org

Okotoni, O \& Erero, J. (2005). Manpower Training and Development in the Nigeria Public Service, Retrieved on $28^{\mathrm{TH}}$ January 2019. http://unpan1.un.org/intradoc/groups/public/documents/AAPAM/UNPAN026993.pdf

Igbaekemen, G.O. (2014). Capacity Building-A Tool for increased productivity in Nigeria Public Sector Organization; Global Journal of Human Resources management 2(3) 45-58; Published by European Centre for Research, Training and Development. UK, www.eajournals.org. Accessed January 23rd 2019

Obisi, C. (2011), Employee Training and Development in Nigeria Organizations: Some Observations and Agenda for Research. African Journal of Business and Management Research, 1(9) 82-91

Raja, A. G., K.; Furqan A. K., \& Muhammad, A. K. (2011). Impact of Training and Development on Organizational Performance. Global Journal of Management and Business Research. 11(7) Global Journals Inc. (USA)

Anam, A., Rashid, S. \&. Rab. N. L. (2013). The Impact of Employees Training On the Job Performance in Education Sector of Pakistan; Middle-East Journal of Scientific Research 17 (9) 